\title{
Penggunaan PAC pada Limbah Cair Industri Tahu
}

\author{
Dwi Hudiyanti \\ Laboratorium Kimia Fisika, Jurusan Kimia F-MIPA UNDIP Semarang
}

\begin{abstract}
ABSTRAK
Telah dilakukan penelitian tentang kemungkinan penggunaan PAC pada pengolahan limbah cair industri tahu. Penelitian dilakukan dengan mengukur turbiditas limbah cair industri tahu pada konsentrasi PAC yang bervariasi; 0 sampai $70 \mathrm{mg} / 30 \mathrm{~mL}$ sampel. Penelitian dilaksanakan pada suhu $28{ }^{\circ} \mathrm{C}, 1 \mathrm{~atm}$, serta waktu pendiaman setelah penambahan PAC tetap, yaitu 100 menit. Hasil penelitian menunjukkan bahwa penambahan PAC pada limbah cair industri tahu memberikan perubahan kekeruhan yang menurun kemudian naik dan turun lagi. Dari hasil penelitian dapat disimpulkan bahwa : pertama, kestabilan sistem koloid dalam limbah cair industri tahu berubah dengan perubahan konsentrasi PAC yaitu bridging flocculation, lalu steric stabilization kemudian depletion flocculation, kedua, PAC dapat digunakan untuk menjernihkan (menurunkan kekeruhan) limbah cair industri tahu. Diperkirakan penurunan kekeruhan akan optimal pada penambahan PAC sebesar $12 \mathrm{mg} / 30 \mathrm{~mL}$ limbah.
\end{abstract}

(Kata kunci : PAC, limbah tahu, turbiditas, bridging flocculation, steric stabilization, depletion flocculation)

ABSTRACT

The possibility of using PAC for treating of wastewater of tofu industry had been investigated. Research was done by measuring turbidity of the wastewater when PAC concentration was varied from 0 to 70 $\mathrm{mg} / 30 \mathrm{~mL}$ sample. All experiment were done at $28^{\circ} \mathrm{C}, 1 \mathrm{~atm}$, and settling time after PAC addition was constant, i.e. 100 minutes. Result showed that addition of PAC altered the turbidity, at first it was decreased, and then it was increased and finally it was decreased again. The conclusion are : first, the stability of colloidal system in wastewater of tofu industry change with the changes of PAC concentration, i.e. bridging flocculation, then steric stabilization and followed by depletion flocculation; second, PAC can be used for cleaning (reducing the turbidity of) wastewater of tofu industry. It is predicted that the reduction of turbidity will be optimum at PAC addition $12 \mathrm{mg} / 30 \mathrm{~mL}$ sample.

(Keywords : PAC, wastewater of tofu, bridging flocculation, steric stabilization, depletion flocculation)

Telah dipresentasikan pada Seminar Pengembangan MIPA 1998, FMIPA UNDIP, tanggal 28 November 1998

\section{PENDAHULUAN}

Polusi, baik udara tanah maupun air merupakan suatu keadaan yang sekarang banyak menjadi problema yang harus segera ditangani. Hal ini disebabkan karena dampaknya yang begitu luas baik dari segi sosial, ekonomi maupun budaya.
Salah satu industri yang potensial untuk menimbulkan polusi adalah industri tahu. Air limbah buangan industri tahu, terutama adalah industri rumah tangganya, umumnya masih banyak mengandung protein yang dapat menyebabkan berbagai macam persoalan jika dibuang dengan 
begitu saja ke badan sungai. Diantaranya adalah kekeruhan dan bau yang ditimbulkan bila protein tersebut telah mengalami pembusukan.

Kekeruhan atau hamburan cahaya [1] merupakan sifat dari suatu sistem koloid yang terjadi karena adanya partikel-partikel yang terdispersi dalam sistem tersebut. Salah satu cara untuk mengurangi kekeruhan adalah dengan mengendapkan partikel-partikel penyebab kekeruhan tersebut. Pengendapan partikel-partikel koloid dapat dilakukan dengan menambahkan suatu flokulan. Flokulan akan mengikat partikel-partikel dalam suatu kerangka tiga dimensi sehingga mempunyai massa yang cukup besar untuk mengendap. Flokulan yang akan dicobakan dalam penelitian ini adalah PAC (polyaluminium klorida) [2]. Penelitian dilakukan untuk mengetahui pengaruh PAC terhadap kekeruhan dari sampel limbah sehingga dapat diperkirakan kemungkinan penggunaan PAC pada pengolahan limbah cair industri tahu.

Suatu sistem koloid dikatakan stabil jika tidak ada partikel-partikel yang menempel satu dengan lainnya pada saat terjadinya tumbukan antar partikel-partikel tersebut. Tumbukan terjadi karena setiap partikel dalam sistem koloid akan bergerak secara acak dan terus menerus yang disebut sebagai gerak Brown.

Suatu sistem koloid yang tidak stabil akan mengalami aggregasi pada saat terjadinya tumbukan antar partikel. Proses pembentukan aggregat ini disebut sebagai koagulasi atau juga flokulasi. Koagulasi biasanya digunakan untuk untuk proses aggregasi yang terjadi karena gaya tarik van der Waals antara partikel-partikel koloid sedangkan flokulasi digunakan untuk aggregasi yang terjadi karena adanya polimer. Koagulasi biasanya menghasilkan aggregat yang padat/masif sedangkan flokulasi menghasilkan struktur yang lebih renggang [3].

Efek polimer pada kestabilan sistem koloid yang paling banyak dikenal adalah steric stabilization [4,5]. Dalam hal ini stabilitas terjadi oleh adanya molekuimolekul polimer yang teradsorbsi atau terikat pada permukaan partikel-partikel koloid. Stabilisasi sterik akan efektif bila sistem dapat memenuhi beberapa kondisi : pertama, ikatan cukup baik; kedua, penutupan permukaan harus sempurna; dan, ketiga, ketebalan lapisan sterik harus cukup besar.

Selain itu polimer yang terikat juga dapat menyebabkan terjadinya bridging flocculation. Ruehrwein dan Ward (1952) [6] merupakan yang pertama mengusulkan bahwa flokulan polimer berfungsi dengan mekanisme pembentukan jembatan polimer (bridging flocculation). Pembentukan jembatan ini dipandang sebagai konsekuensi dari àdsorpsi segmen dari molekul-molekul flokulan polimer pada permukaan lebih dari satu partikel. Jembatan ini menghubungkan partikelpartikel bersama-sama menjadi aggregat yang renggang, yang seringkali dengan cepat mengendap atau dengan mudah diambil dengan filtrasi.

Polimer yang berada bebas dalam larutan juga dapat mempengaruhi kestabilan sistem koloid yang dikenal dengan nama depletion flocculation. Gaya yang menyebabkan terjadinya flokulasi jenis ini pertama kali diketahui oleh Asakura dan Oosawa (1954) [7]. Gaya ini muncul setiap kali partikel-partikel koloid saling mendekat sedemikian sehingga rantai-rantai polimer terusir dari daerah antar partikel tersebut. Secara kasar dapat dikatakan bahwa 
terusirnya (depletion) molekul-molekul polimer terjadi jika jarak antar partikel kurang dari 'diameter' molekul polimer. Dalam jarak tersebut rantai polimer hanya dapat berada diantara partikel dengan cara kompresi. Cara ini menyebabkan hilangnya entrophi konfigurasi yang secara termodinamika tidak disukai. Pengusiran rantai polimer dari daerah diantara partikel berarti bahwa telah terbentuk mikroreservoir dari solven murni pada zona antarpartikel. Oleh karena itu pendekatan yang lebih rapat lebih disukai dalam solven yang baik karena menghasilkan penurunan energi bebas ketika solven murni didorong dari daerah di antara partikel-partikel dan bercampur secara spontan dengan larutan polimernya.

\section{METODOLOGI PENELITIAN}

Pada penelitian ini sampel yang digunakan adalah sampel segar air buangan industri tahu pada skala rumah tangga. Diasumsikan bahwa sampel tersebut merupakan sistem koloid dengan fasa terdispersinya protein dalam medium air. Suhu dan tekanan pada saat penelitian adalah suhu dan tekanan ruang $\left(28^{\circ} \mathrm{C}\right.$, $1 \mathrm{~atm}$ ) dan dianggap konstan.

\section{Pengambilan Sampel}

Sampel air buangan tahu diambil dari industri rumah tangga yang terletak di desa Kalidoh, Kecamatan Babadan, Kabupaten Semarang. Sampel yang diambil adalah sampel segar berupa supernatan pada pembuatan tahu sebagai produk limbah sebelum dibuang ke perairan.

\section{Variabel penelitian} adalah :

Dalam penelitian ini variabel yang diukur

- variabel terikat adalah waktu, suhu, dan $\mathrm{pH}$

- variabel bebas adalah dosis flokulan PAC

\section{Parameter Penelitian}

Pada penelitian ini parameter yang digunakan adalah kekeruhan dari supernatan setelah diberi perlakuan,

\section{Alat dan Bahan}

Beberapa alat yang digunakan dalam penelitian ini adalah : turbidimeter merek Orbeco-Hellige, pengaduk magnit merek Stuart Scentific, pH meter merek Orion model $420 \mathrm{~A}$ serta alat-alat gelas standar.

Bahan flokulan yang digunakan dalam penelitian adalah PAC komersial.

\section{Cara kerja}

Sejumlah sampel segar air buangan tahu masingmasing sebanyak $30 \mathrm{ml}$ ditambah dengan PAC dengan konsentrasi bervariasi dari 0 sampai 70 $\mathrm{mg} / 30 \mathrm{ml}$. Kemudian masing-masing sampel diaduk dengan pengaduk magnit skala 1 selama 2 menit. Setelah itu sampel didiamkan untuk memberi kesempatan pada flok-flok yang terbentuk agar dapat mengendap. Pendiaman dilakukan selama 100 menit. Supernatan yang diperoleh setelah pendiaman diukur kekeruhannya secara turbidimetri.

Pengukuran kekeruhan dilakukan dengan mengencerkan $5 \mathrm{ml}$ supernatan menjadi $130 \mathrm{ml}$. Kemudian hasil pengenceran diukur kekeruhannya dengan turbidimeter.

Analisa data dilakukan dengan membuat grafik kekeruhan terhadap konsentrasi PAC yang ditambahkan. Dari grafik diharapkan dapat dilihat konsentrasi PAC optimum untuk penurunan kekeruhan limbah tersebut.

\section{HASUL DAN PEMBAHASAN}

Air limbah industri tahu mempunyai kekeruhan yang tinggi. Kekeruhan ini diperkirakan berasal dari adanya protein yang terdispersi dalam ukuran koloid yang merupakan sisa dari proses pembuatan tahu.

Tahu merupakan hasil proses denaturasi protein yang berasa dari kedele. Sehingga diasumsikan bahwa penyebab kekeruhan pada limbahnya adalah sisa-sisa 
protein yang tidak terambil pada pembuatan tahu ini. Sisa protein dengan kadar yang relatif tinggi pada air limbah, oleh adanya mikroorganisme, akan mengalami pembusukan yang sangat mengganggu lingkungannya.

Kadar protein ini periu ditekan agar sisa protein yang dibuang ke lingkungan tidak terlalu tinggi. Salah satu cara yang banyak digunakan pada pengolahan limbah cair adalah metode koagulasi atau flokulasi dengan penambahan bahan koagulan atau flokulan. Pada penelitian ini dicoba digunakan flokulan PAC. Diharapkan bahwa flokulan ini akan dapat menyebabkan flokulasi dari sisa-sisa protein sehingga dengan mudah dapat dipisahkan dari sistem tersebut.

Protein adalah suatu makromolekul yang dapat bermuatan positif maupun negatif tergantung pada $\mathrm{pH}$ lingkungannya. Demikian pula dengan PAC dapat bermuatan positif maupun negatif tergantung pada pH-nya. Oleh karena itu diperkirakan akan tekbentuk interaksi diantara keduanya melalui muatan-muatan ini sehingga akan terjadi suatu bridging flocculation.

Dari data yang diperoleh (lampiran 1) dapat dibuat grafik perubahan kekeruhan terhadap perubahan konsentrasi PAC sebagai berikut :

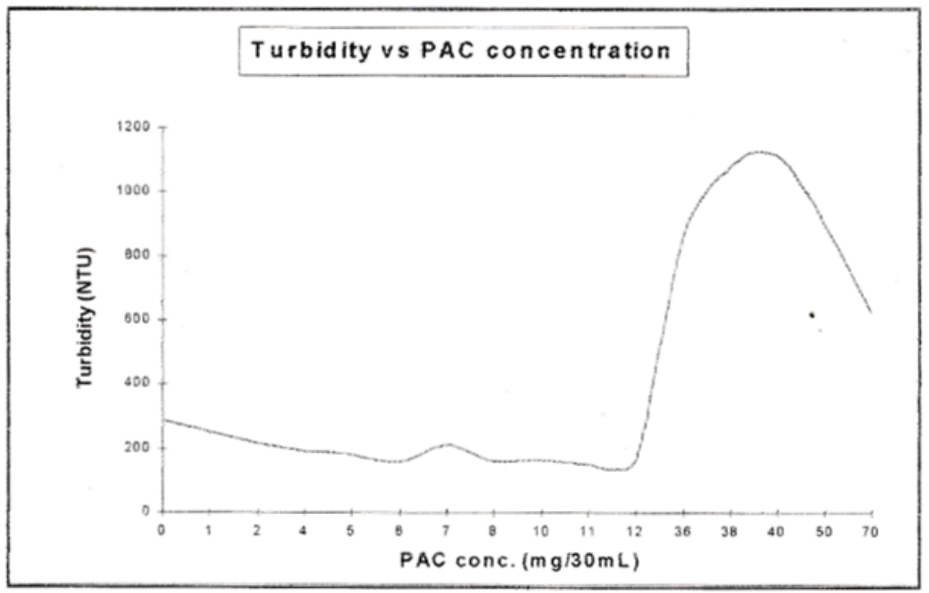

Gambar 1: Perubahan Kekeruhan karena perubahan konsentrasi PAC

Grafik tersebut menunjukkan adanya penurunan kekeruhan dengan bertambahnya konsentrasi PAC yang ditambahkan. Namun demikian penurunan tersebut hanya terjadi sampai dengan konsentrasi tertentu saja, dalam hal ini sampai sekitar $12 \mathrm{mg} / 30$ $\mathrm{mL}$. Setelah itu kekeruhan menjadi naik sampai suatu batas optimum kemudian turun kembali. Penurunan yang kedua terjadi sangat drastis sedangkan yang pertama landai.
Hasil tersebut menunjukkan bahwa penambalian PAC pada limbah cair industri tahu dapat menurunkan kekeruhannya namun penambahan tersebut tidak dapat diberikan dengan bebas. Terdapat dosis optimum untuk penambahan tersebut agar penurunan kekeruhan optimal. Dari grafik diatas diperkirakan bahwa penurunan optimal terjadi pada dosis $12 \mathrm{mg} / 30 \mathrm{~mL}$. Penambahan tersebut akan mengoptimalkan pembentukan flok yang mengikat partikel- 
partikel terdispersi dalam limbah sehingga pengendapannya optimal.

Pada dosis yang lebih besar diperkirakan terjadi restabilisasi partikelpartikel karena seluruh permukaan partikel tertutup oleh PAC sehingga partikel-partikel akan mempunyai muatan yang sama dan saling tolak menolak. Akibatnya partikelpartikel tidak dapat beragregasi untuk membentuk partikel yang lebih besar. Sehingga partikel akan tetap terdispersi dan tidak dapat mengendap.

Berdasarkan teori yang ada dapat diperkirakan bahwa proses di atas merupakan suatu proses perubahan kestabilan suatu sistem koloid karena adanya perubahan konsentrasi polimer yang ditambahkan. Perubahan tersebut dapat digambarkan sbb (gambar 2) :

- Pada tahap awal karena jumlah polimer yang ditambahkan masih relatif sedikit maka polimer, dalam hal ini PAC, kan terikat pada lebih dari satu partikel sehingga terjadi jembatan polimer atau bridging flocculation yang menyebabkan ketidakstabilan sistem. Partikel-partikel bergabung membentuk masa yang lebih besar sehingga dengan mudah akan mengendap. Supernatan yang tersisa menjadi lebih jernih atau kekeruhannya menjadi turun. Hal inilah yang terjadi pada konsentrasi PAC dibawah $12 \mathrm{mg} / 30 \mathrm{~mL}$.
- Pada konsentrasi diatas $12 \mathrm{mg} / 30 \mathrm{~mL}$ maka penutupan permukaan partikel oleh polimer akan lebih baik. Mulai terjadi tolakan antar partikel-partikel yang tertutupi tersebut karena adanya rantai-rantai polimer yang menghalangi partikel-partikel tersebut untuk bergabung. Akibatnya terjadi kestabilan dari sistem koloid tersebut, terjadi stabilisasi sterik. Supernatan akan tetap keruh atau bahkan menjadi lebih keruh karena diameter partikel menjadi yang lebih besar.

- Pada konsentrasi yang lebih besar lagi maka pada sistem tersebut terdapat banyak molekul-molekul polimer yang tidak berikatan dengan partikel dan berada bebas di dalam sistem tersebut. Molekul-molekul polimer ini mempengaruhi kestabilan sistem tersebut karena pada jarak antar partikel yang relatif rendah, kurang dari diameter molekul polimer, maka molekulmolekul polimer yang bebas tersebut akan terusir dari daerah diantara partikel tersebut. Pengusiran ini karena untuk berada pada daerah antara ters but maka polimer harus mengalami kompresi yang diikuti dengan hilangnya entrophi konfigurasionalnya. Terusirnya molekul polimer bebas ini menyebabkan terjadinya flokulasi dari partikel-partikel tersebut, terjadi depletion flocculation.
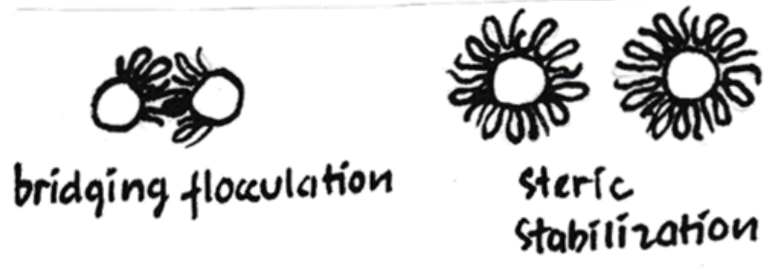

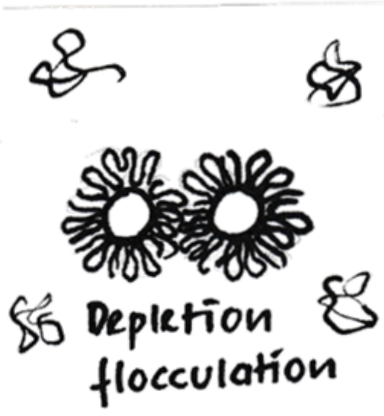

Gambar 2 : Pengaruh polimer pada kestabilan sistem koloid pada air limbah industri tahu 
Jadi oleh adanya PAC terjadi perubahan kestabilan dari sistem koloid dalam air limbah industri tahu yaitu dari bridging flocculation pada konsentrasi rendah ke steric stabilization kemudian pada konsentrasi yang lebih tinggi lagi menjadi depletion flocculation. Dengan demikian maka penambahan PAC untuk menurunkan konsentrasi protein pada air limbah tahu harus diatur konsentrasinya agar diperoleh hasil sesuai dengan yang diinginkan. Dalam hal ini penurunan konsentrasi protein yang optimal, terlihat dari penurunan kekeruhannya, terjadi pada konsentrasi PAC $12 \mathrm{mg} / 30 \mathrm{~mL}$.

\section{KESIMPULAN}

Kesimpulan yang dapat diambil dari penelitian ini adalah : pertama, kestabilan sistem koloid dalam limbah cair industri tahu berubah dengan perubahan konsentrasi PAC yaitu bridging flocculation, lalu steric stabilization kemudian depletion flocculation; kedua, PAC dapat digunakan untuk menjernihkan (menurunkan kekeruhan) limbah cair industri tahu. Diperkirakan penurunan kekeruhan akan optimal pada penambahan PAC sebesar 12 $\mathrm{mg} / 30 \mathrm{~mL}$ limbah.

\section{UCAPAN TERIMA KASIH}

Ucapan terima kasih penulis sampaikan pada Drs. Damin Sumardjo yang telah banyak meluangkan waktu untuk memberikan bimbingan dan arahan pada penelitian ini. Demikian juga kepada sdr. Tri Suhartini yang telah membantu pada pengambilan data untuk penelitian ini.

\section{DAFTAR PUSTAKA}

1. Hunter, R. J., Matarese, R. and Napper, D. H. (1983) Colloids Surfaces 7, 1-13

2. Enggono, J., 19..., Pengolahan Air dengan Poly Aluminium Chlorida, PT. Primapackimia Rejeki

3. Hunter, R.J., 1993, Foundations of Colloid Science Vol.1, Oxford University Press, Oxford, 452

4. Heller, W. and Pugh, T.L., 1954, J. Chem. Phys.22, 1778

5. op. cit. 2,454

6. Ruehrwein, R. A. and Ward, D. W. (1952), Soil Sci. 73, 485

7. Asakura, S. and Oosawa, F. (1954), J. Chem. Phys. 22, 1255

Diterima : Desember 1998, Direvisi dan telah diterima kembali : Januari 1999 